\title{
EVALUATION OF PEARL MILLET AND MUNGBEAN INTERCROPPING SYSTEMS IN ARID REGION OF RAJASTHAN (INDIA)
}

\author{
Kalu Ram and RS MeenA* ${ }^{1}$ \\ Swami Keshwanand Rajasthan Agricultural University, Bikaner-334 006, India
}

Key words: Intercropping, Row ratio, Yield Indices

\begin{abstract}
A field experiment was conducted during kharif season, 2011 to evaluate different row ratio of pearl millet with mungbean in the arid region of Rajasthan. The treatments comprised of sole pearl millet at $45 \mathrm{~cm}$ spacing, one sole mungbean and ten pearl millet with mungbean treatments row in different ratio. The intercropping of pearl millet with mungbean in $1: 7$, followed by $2: 6$ and $1: 3$ row ratio produced maximum pearl millet equivalent yield (PMEY), land equivalent ratio (LER), aggresivity, net returns,benefit cost (B : C) ratio and also better nutrient uptake by these treatments compared to sole and other intercropping treatments. Aggressivity values showed that inter crop mungbean did not offer any competition to pearl millet in different row ratio, while relative crowding coefficient (RCC) values indicated was a yield disadvantage in mungbean in all the intercropping system except 1: 7 row ratio.
\end{abstract}

Farmers in the arid and semi arid regions practices generally mix/intercrop pearl millet (Pennisetum glaucum (L.) Br. Emend Stuntz) with legumes to increase productivity per unit area or avoid risk of failure of crops as the legume crops, especially mungbean are more stable in grain yields in arid region. The spatial arrangement in intercropping has important effects on the balance of competition between component crops, productivity, economics, energetics and soil fertility status which varies with region and crop (Kumar et al. 2006). Information regarding geometrical requirement of intercropping that suits to the farmer's of arid region was scanty, particularly with pearlmillet. In the research work various combinations of pearlmillet and mungbean with row ratios were studied.

Field experiment on pearl millet and mungbean intercropping was conducted during kharif season of 2011 at Agronomy Farm, College of Agriculture, Bikaner, Rajasthan (India). The soil of the experimental site was loamy sand and having $156.33 \mathrm{~kg} / \mathrm{ha}$ alkaline permanganate oxidizable N (Subbiah and Asija 1956), $16.05 \mathrm{~kg} / \mathrm{ha}$ available P (Olsen et al. 1954), $221.0 \mathrm{~kg} / \mathrm{ha} 1 \mathrm{~N}$ ammonium acetate exchangeable K (Stanford and English 1949) and $0.80 \%$ organic carbon (Jackson 1973). The $\mathrm{pH}$ of soil was 8.4 (1: 2.5 soil and water ratio). Field capacity, permanent wilting point and bulk density recorded were $8.4 .0(\mathrm{w} / \mathrm{w}), 1.1 .83 \%(\mathrm{w} / \mathrm{w})$ and $1.66 \mathrm{Mg} / \mathrm{m} 3$, respectively in 0-30 cm soil depth. Plant to plant spacing was $10 \mathrm{~cm}$ in all treatments, the treatments comprised of sole pearlmillet sowing at $45 \mathrm{~cm}$ row to row spacing. In intercropping treatments row to row distance maintained was $30 \mathrm{~cm}$ and sowing was done by "pora" (Indigenous plough) method in open furrow on 15 July, 2011.one sole mungbean and ten pearlmillet with mungbean treatments $(1: 3,1: 7,2: 2,2: 6,3: 1,3: 5,4: 4,5: 3,6: 2$ and $7: 1$ row ratio) replicated four in randomized block design (RBD). Crop received $216.9 \mathrm{~mm}$ of rainfall in 10 days in the growing season. $20 \mathrm{~kg}$ each of $\mathrm{N}$ and $\mathrm{P}_{2} \mathrm{O}_{5} /$ ha was applied as uniform basal dose at the time of sowing. Remaining $20 \mathrm{~kg} \mathrm{~N} / \mathrm{ha}$ was applied as top dressed in the pearlmillet rows only at 30 days after sowing. All the data were statistically analyzed using the F-test (Gomez and Gomez 1984).

\footnotetext{
*Author for correspondence: <rsmeenaagro@gmail.com>. ${ }^{1}$ Present address: Department of Agronomy, Institute of Agricultural Sciences, Banaras Hindu University, Varanasi-221 005, India.
} 
Sole pearl millet $(45 \mathrm{~cm})$ recorded maximum higher number of effective tillers/plant. The grain yield of sole pearl millet was significantly higher $(1427 \mathrm{~kg} / \mathrm{ha})$ as compared to all other intercropping systems while remained at par with intercropping treatments of $7: 1$ row ratio. However, $7: 1$ row ratio (Table 1 (was significantly higher than all other row ratio except that of 3 $: 1$ and $6: 2$ row ratio treatments. Stover yield was significantly higher observed (2990 kg/ha) of sole pearl millet as compared to all other intercropping treatments which remained at par with intercropping treatments of $3: 1,5: 3,6: 2$ and $7: 1$ row ratio. Among intercropping treatments, row ratio of 7: 1 was significantly higher over all other row ratio except that of 3:1, 5: 3 and 6: 2 row ratio treatments. The reduction in yield of pearlmillet and mungbean in the intercropping system was mainly due to reduction in plant stand of pearlmillet and mungbean in different intercropping treatments as replacement type of intercropping system was followed in the present study. These results are similar to those of Kumar et al. (2006) and Kuri et al. (2012).

The maximum and higher mean pearlmillet grain equivalent yield (4036 kg /ha) was obtained under pearlmillet with mungbean 1: 7 row ratio compared to all other intercropping treatments and it was statistically at par with sole mungbean This might be because of additional yield of pearlmillet and mungbean was recorded in 1: 7 row ratio intercropping system as 12.5 per cent plant population of pearlmillet produced 36.5 per cent of sole pearlmillet yield. Similarly 87.5 per cent plant population of mungbean recorded 90.19 per cent of sole mungbean yield in this row ratio. This was further confirmed by relative crowding coefficient value (RCC) of these row ratios (Table 1) which indicated that there was no yield disadvantage in mungbean in 1: 7 row ratio. Whereas in case of pearlmillet there is yield advantage in all intercrop combinations. Mungbean had yield advantage only in 1: 7 row ratio treatments Tetarwal and Rana (2006) also recorded similar observations. The land equivalent ratio (LER) of all intercropping treatments were higher than sole pearlmillet and there was maximum, 28 percentage in $1: 7$ row ratio treatments respectively followed by $2: 2,1: 3$ and $2: 6$ row ratio treatments (Table 1 ). This indicated that highest yield advantage of mixing of crops in these treatments. Aggressivity of the intercropping treatments have positive sign value which indicates that in pearl millet + mungbean intercropping system, mungbean did not offer any competition to pearl millet in different row ratios studied (Table 1).

The total uptake of nitrogen sole pearlmillet was significantly higher over all other intercropping treatments but remained at par with $7: 1$ and $6: 2$ row ratio. Total P uptake was obtained in sole pearlmillet was statistically at par with $7: 1$ row ratio but significantly higher than all other treatments. These results confirmed the findings of those of Tetarwal and Rana (2006) who have reported that the total uptake of $\mathrm{N}$ and $\mathrm{P}$ was significantly higher with sole pearlmillet. The total uptake of nitrogen and phosphorus recorded under sole mungbean and $1: 7$ row ratio was maximum. Singh (1992) also reported similar results. The intercropping treatment gave significantly higher net return and B:C ratio (Table 1 ) over sole crop obviously due to higher grain and stover/ straw yield obtained with these treatments. In pearl millet + Mungbean at $1: 7$ row ratio observed maximum net return ( $₹ 36380 / \mathrm{ha}$ ) but statistically at par with sole mungbean ( ₹ 34353/ha), while B : C ratio observed maximum in pearl millet + mungbean at $1: 7$ row ratio. Hooda et al. (2004), Kuri et al. (2012) also reported that intercropping of pearlmillet with greengram recorded highest net return and $\mathrm{B}$ : C ratio over sole pearlmillet.

\section{References}

Gomez KA and Gomaz AA 1984. Statistical Procedures for Agricultural Research. John Wiley \& Sons, Singapore. pp 693.

Hooda RS, Khippal A and Narwal RP 2004. Effect of fertilizer application in conjunction with bio-fertilizers in sole and intercropping system of pearlmillet under rainfed condition. Haryana J. Agron. 20(1): 29-30. 
Jackson ML 1973. Soil Chemical Analysis. Prentice Hall of India Pvt. Ltd., New Delhi.

Kumar P, Hooda RS, Singh H and Nanwal RK 2006. Economics of pearlmillet legume association as influenced by intercropping and strip cropping system in sandy loam soils. Haryana Arg. Univ. J. Res. 36: 101-04.

Kuri BR, Yadav RS and Kumawat A 2012. Evaluation of pear lmillet (Pennisetum glaucum) and mothbean (Vigna acconitifolia) intercropping systems in hyper arid partially irrigated north-western plains zone. Indian J. Agric. Sci. 82(11): 993-996.

Olsen SR, Cole CV, Watanabe FS and Dean LA 1954. Estimation of available phosphorus in soils by extraction with sodium bicarbonate. USDA Circ. No. 939, Washington.

Singh P 1992. Studies on comparative performance of pearlmillet (Pennisetum americanum (L.), Leek) based intercropping system with different phosphorus level. M.Sc. (Ag.) Thesis, Rajasthan Agricultural University, Bikaner (Rajasthan). pp. 59-63.

Stanford S and English L. 1949. Use of flame photometer in rapid soil tests for K and Ca. Agron. J. 41: 446447.

Subbiah BV and Asija GL. 1956. A raped processor of determination of available nitrogen in nitrogen in soil. Curr. Sci. 25: 259-260.

Tetarwal JP and Rana KS 2006. Impact of cropping system, fertility level and moisture conservation practices on productivity, nutrient uptake, water use and profitability of pearlmillet (Pennisetum glaucum) under rainfed condition. Indian J. Agron. 51(4): 263 -266.

(Manuscript received on 24 July, 2013; revised on 3 March, 2014) 